\title{
Socket Adapter Device
}

National Cancer Institute

\section{Source}

National Cancer Institute. Socket Adapter Device. NCI Thesaurus. Code C49809.

A device designed to allow an incompatible plug to connect with another device. 